This item was submitted to Loughborough's Research Repository by the author.

Items in Figshare are protected by copyright, with all rights reserved, unless otherwise indicated.

\title{
Gold in Ghana: The effects of changes in large-scale mining on artisanal and small-scale mining (ASM)
}

\section{PLEASE CITE THE PUBLISHED VERSION}

https://doi.org/10.1016/j.exis.2018.09.009

\section{PUBLISHER}

(c) Crown. Published by Elsevier

\section{VERSION}

AM (Accepted Manuscript)

\section{PUBLISHER STATEMENT}

This paper was accepted for publication in the journal The Extractive Industries and Society and the definitive published version is available at https://doi.org/10.1016/j.exis.2018.09.009.

\section{LICENCE}

CC BY-NC-ND 4.0

\section{REPOSITORY RECORD}

Yankson, Paul W.K., and Katherine Gough. 2018. "Gold in Ghana: The Effects of Changes in Large-scale Mining on Artisanal and Small-scale Mining (ASM)”. figshare. https://hdl.handle.net/2134/35688. 


\title{
Gold mining in Ghana: The effects of changes in large-scale mining on artisanal small-scale mining
}

\author{
Paul W.K. Yankson and Katherine V. Gough
}

\begin{abstract}
Two scales of gold mining operations, artisanal and small-scale mining (ASM) and large-scale mining, have operated side by side in Ghana for decades. In the past, the two co-existed on the same mineralised land without much contact or conflict, as large-scale mining occurred underground and ASM operated mainly on the surface. With the former's transition from an underground labour-intensive mining operation to capital-intensive surface activity, however, opportunities for wage employment have reduced leading to labour retrenchment. Using an informalisation theoretical framework, and drawing on fieldwork conducted in the three gold mining towns of Obuasi, Prestea and Kenyasi, this paper explores how the interface between large-scale mining and ASM has evolved. It is shown how the loss of wage employment opportunities in large-scale mining has contributed to the proliferation of illegal ASM operations. As large-scale surface mining operations have reduced access to mineralised land by ASM, the latter have encroached on to the concessions of the former resulting in conflicts between these parties. It is ASM rather than large-scale mining, however, that is sustaining local economies in Ghana. As the economic well-being of mining towns is linked largely to the fortune of their mining economies, it is imperative that an innovative approach is adopted by the state in addressing the need for ASMs to access mineralised land.
\end{abstract}

Key words: mining; gold; employment; urban; Ghana 


\section{Introduction}

Gold mining has been carried out in the former Gold Coast, now Ghana, for centuries (OfosuMensah, 2011a). Artisanal gold mining started in the gold-rich areas long before modern largescale gold mining (Hilson, 2002a) and was one of the mainstays of the numerous Akan states that developed in the forest belt of Ghana (Dumett, 1979, 1998; Kea, 1982). Since colonial rule and the introduction of modern, large-scale concession-based mining in Ghana, artisanal mining has been treated as an informal sector. Until the last couple of decades, the two different scales of mining co-existed, accessing the same land resource but mostly operating at differing depths using different techniques; artisanal and small-scale mining (ASM) operated mostly on the surface, while large-scale mining activities occurred underground. Although in some cases ASM took place on the active large-scale mine concessions, their operations were to some extent tolerated.

Since the implementation of the International Monetary Fund and World Bank's Economic Recovery Programme (ERP) and successive Structural Adjustment Programmes (SAPs) in Ghana in the 1980s, the government has established a more attractive investment climate for foreign mining companies. The consequent rapid rise in foreign-financed mineral exploration and mining activities has displaced thousands of existing local artisanal and small-scale gold mine operators (Akabzaa and Darimani, 2001; Hilson, 2001, 2004), sparking conflict between these parties over access to land (Hilson and Potter, 2005). Moreover, technological changes in large-scale mining have caused labour contraction, reducing opportunities for wage employment and catalysing an outflow of mine-retrenched labour into illegal ASM operations. The rapidly rising price of gold on the world market since 2001 has been an added factor in the absorption of thousands of displaced people from land concessions into ASM (Banchirigah, 2007).

The rising prevalence of ASM operations has led to discussions regarding the increasing incidence of informality of mine employment, and its corresponding marginality and illegality, despite government attempts at their formalisation. This paper makes an important contribution to the literature by exploring the relationship between actors engaged in the formal mining sector (i.e. large-scale mining companies and state agencies) and informal ASM. By adopting a labour informalisation approach, the effects of changes in large-scale mining on their relationship with ASM, particularly on the latter's access to mineralised land and changing occupational patterns, 
are examined in three gold mining towns. It is argued that as the economic well-being of mining towns is linked largely to the fortune of their mining economies, it is imperative that an innovative approach is adopted to addressing the needs of the expanding ASM sector.

After this introduction, the next section presents the field research methods followed by a conceptual discussion of the informalisation framework used in analysing the relationship between large-scale mining and ASM. Subsequently, a brief presentation of the roles of both mining types in national development is made. Changes in large-scale mining and their effects on ASM are then explored, drawing on data from the three case study mining towns of Obuasi, Prestea and Kenyasi. The paper ends with concluding statements highlighting the need to address the marginality of ASM in regards to accessing mineralised land, in order to ensure their inclusiveness and the sustainability of gold mining in Ghana.

\section{Field research methods}

This paper is based on research conducted as part of a major study which explored the connection between mining and urbanisation in Angola, Ghana and Tanzania. In Ghana, the link between gold mining and urban growth, livelihoods, poverty and wealth was examined in three gold mining towns with differing characteristics: Obuasi was selected to represent old mining urban centres dominated by a large-scale mining company; Prestea was selected as an old mining centre with the presence of a large-scale mining company, though mining there is now dominated by ASM operations; and Kenyasi was selected to represent a new mining centre dominated by ASM, though there is a large-scale mining company operating nearby.

A three-stage approach was adopted in collecting primary data in all three towns. Initially qualitative data was collected by conducting key informant interviews with a range of respondents living in the mining settlements, and a focus group discussion was held with young people (a mixed group of males and females) in each of the three settlements. Often the first interviewees were an elderly man and woman who were asked about the history of the settlement and for their account of the changes they had observed, including the role played by gold mining. Perceptions about both the positive and negative effects of mining in the towns and surrounding areas were ascertained from all of the respondents. Although the settlements were selected as being primarily involved in large or small-scale mining in line with the rest of the project, in Ghana the two often go hand in hand thus in each settlement miners working for a large-scale 
mining company as well as miners operating in ASM were interviewed. In each settlement the ASM mining sites were visited and informal discussions were held with miners and business owners. Interviews were also conducted with officials of service providers in education, health and local government, as well as a range of officials in local government units (the Municipal/District Assemblies), in particular Town Planning Officers and Environmental Health Officers.

The second stage of fieldwork entailed collecting quantitative data using a household questionnaire survey. In each town, two neighbourhoods in the central areas of the towns and two with peripheral locations were selected. Each neighbourhood was divided into four quadrants, to ensure that there was a geographical spread of sampled houses, and a random sampling method was used for selecting houses within each quadrant. When the selection fell on a compound house inhabited by more than one household, the one that was interviewed was selected using random numbers. Given the differing sizes of the settlements, 40 questionnaires were conducted in each neighbourhood in Obuasi (total 160), 30 in each neighbourhood in Prestea (total 120), and 20 in each neighbourhood in Kenyasi (total 80) resulting in a total of 360 questionnaires. A range of issues was covered including: livelihoods, employment, mobility, changing role of mining, and household income and assets.

The third fieldwork stage focused on interviewing policy makers in Accra. Key officials in a number of Ministries, Departments and Agencies were interviewed along with the relevant Member of Parliament representing the electoral constituencies of the three towns. The interviews were directed at seeking information about the policies, programmes and changes that have occurred regarding mining and their impact on the towns and the wider environment in the selected settlements and beyond. Interviews with officials of the Minerals Commission carried out in Accra and Tarkwa by the first author in an earlier study on gold mining area also drawn on in this paper.

\section{Conceptual framework}

This paper adopts an informalisation framework to analyse the relationship between the formal sector, represented by state institutions/agencies and large-scale mining, on the one hand and informal ASM on the other, and the effects of changes in the former on the latter. In most 
instances, informal denotes illegality, since ASM operators tend to conduct mining without registering their activities and hence operate without the legally acquired mining concessions. As lack of access by unregistered ASM to any state support offered to registered miners marginalises them, illegality and marginality are key concepts used in this paper. An alternative conceptual framework at times used to analyse conflict between large-scale mining and ASM in accessing natural resources, in this case mineralised land, is political ecology. The pivot of the political ecology framework is an analysis of power relations between different actors, which can provide a way to explain the uneven distribution of access to environmental resources (Bryant and Bailey, 1997). Power is thus conceptualized as the differential ability to control access to valuable environmental resources in order to gain the economic benefits emanating from resource exploitation (Bryant, 1996; Tan-Mullins, 2007). The state as a principal actor is expected to satisfy the competing needs of all stakeholders and, in the case of mining, access to mineralised land for all types of miners. Bryant and Bailey (1997) point to the use of the political ecology framework to analyse the distribution of costs and benefits related to environmental change and how that reinforces or reduces existing social and economic inequalities and the resultant political implications. As this paper does not focus on the environmental aspects of gold mining but rather analyses the effects of changes in large-scale mining on ASM operations, alongside changes in mining employment and the effects on the economy of the mining towns, an informalisation approach was deemed more appropriate.

Discussions on informality have gained much currency over the last 40 years among academics and policy-making institutions, promoted in particular by the International Labour Organization (ILO, 1972). Defining the informal economy is problematic and current definitions fail to converge around a common construct (Godfrey, 2011). What is generally recognized, however, is that informal economic activities are 'unregulated' or 'escape institutional regulation' and are largely governed by customs and personal ties (Godfrey, 2011). Regulation sets the parameters of legality using a number of dimensions, three of which are particularly pertinent to demarcating formal and informal enterprises: registration and adherence to various governmentdefined bureaucratic procedures; payment of taxes; and compliance with official guidelines on working hours, social security contributions and fringe benefits (Tokman, 1991 cited in Chant, 2008; Williams and Nadin, 2012). The informal economy is the source of employment and 
income for the vast majority of urban dwellers in sub-Saharan Africa, most of whom do not have access to formal sector wage employment (Potts, 2007). ASM, particularly gold and diamonds, has expanded in rural areas of sub-Saharan Africa, including Ghana, where it is often combined with subsistence farming, though the mining has become the primary income-earning activity (Hilson, 2016; Maconachie and Hilson, 2018). In Ghana, however, not much is known about ASM's role in the urban economy, which is usually dominated by non-farm activities, especially commerce, even when large-scale mining is present.

In the 1970 s and 1980s, the informal economy was considered as 'income-generating activities that operated outside the regulatory framework of the state' (Meagher, 2013: 2). The ILO, however, subsequently amended the definition to cover not only informal firms and their workers but also unregistered or unprotected labour working in formal sector firms. This has resulted in a more precise terminology laid out by Chen (2012: 8), which defines economic informality in terms of three central concepts: first, an 'informal sector' encompassing production and employment in unregistered enterprises; second, 'informal employment', involving employment outside labour protection regulations of a given society, whether in formal or informal firms; and third, the 'informal economy', which covers all firms, workers, and activities that operate outside the legal regulatory framework of society and the output that they generate. Artisanal small-scale gold mining in Ghana exhibits these features of informality, the persistence of which has been widely researched (Van Bockstael, 2014; McQuilken and Hilson, 2016; Verbrugge, 2015; Hilson and Hilson, 2015; Verbrugge and Besmanaos, 2016). As Hilson et al. (2017: 82) indicate, there are various schools of thought to explain the persistence of informality of ASM: "(1) the dualists, who see the informal sector as being comprised of marginal activities that provide a safety net for the poor and are distinct from the formal economy; (2) the structuralists, who see the former as being subordinate to the latter; and (3) the legalists, who view unregistered businesses as a response by individuals to bureaucracy".

Since the early 1980s, there has been a shift of focus from informality represented as a marginalized sector to 'informalisation' conceived as a wider economic response to crisis (Meagher, 1995: 259). Informalisation of work has become a global trend, on the increase in both the global North and South (Portes and Schauffler, 1993; Meagher, 1995; Potter and LloydEvans, 1998; Bryceson and Potts, 2006; Lourenco-Lindell, 2008; Schindler, 2014). Within the 
informalisation framework, four issues emerge as key to understanding the role and potential of the informal sector: first, differentiation within the informal sector and the specific characteristics of informal labour; second, linkages between the informal and formal economy; third, the attitude of the state towards the informal sector; and fourth, the role of informal social networks in providing an organizational structure for production and marketing within the informal sector and in providing a framework for the recruitment and use of informal sector labour (Meagher, 1995: 261). For this study, the issue of informal-formal sector linkages, and in particular how the state deals with the informal economy, is important in appreciating the links between the large-scale mining (formal) and ASM (informal) sectors within Ghana's gold mining economy, and how the changes in large-scale mining impact on the operations of ASM alongside patterns of employment changes in the mining settlements.

\section{Evolution of ASM and large-scale mining in Ghana}

Traditional gold mining in Ghana took three forms: washing or 'panning' for alluvial gold along the banks of streams and rivers and along ocean shores, particularly those near river estuaries; shallow-pit surface mining on either the crests or sides of hills or in the sedimented valleys of ancient river beds; and deep-shaft mining for reef gold. The size of the labour force required for traditional mining varied with the type and scale of operations but the indigenous miner prospected for and mined gold together with family members and slaves. Mining was seen as a supplement to subsistence farming and craftwork. Thus, although widespread, the scale of indigenous mining operations was quite limited in size and utilized simple techniques requiring minimum capital and no special skills (Ofosu-Mensah, 2011b). ASM was not considered an illegal activity and the land rights of the artisanal miners were not questioned by any governing authority. The emergence of modern mining from the second half of the $19^{\text {th }}$ century, however, saw the native gold mining industry in Ghana decline due to various factors: the emancipation of slaves, the demonetization of gold dust (1889), which for centuries had been the main medium of exchange, and European imperialism which steadily marginalized Africans from the mining industry as a European mining monopoly emerged (Addo-Fening, 1997, cited in Ofosu-Mensah, 2011b).

Artisanal small-scale mining in Ghana became an informal industrial sector activity, employing thousands of people but featuring largely rudimentary, unmonitored and uncontrolled practices 
(Hilson, 2001), though the original manual operations have become semi-mechanized or mechanized (Hentschel et al., 2002). Consequently, ASM covers a wide span of approaches from rudimentary gold panning, to sophisticated and highly mechanised small-scale mining operations engaging in both hard rock and alluvial mining (COWI, 2016). Artisanal small-scale miners frequently work in collectives comprising from two to twenty or more people, with varying forms of commercial incorporation and business models. ASM units also vary in composition regarding the manpower involved, often including children and women, with individuals or groups specialising in different tasks and using different types of tools depending on whether they work on alluvial deposits or hard rock. In the past, most ASM operations involved the use of simple tools, however, overtime there has been a technological upgrading. In particular, the involvement of Chinese actors in ASM over the last decade or so has transformed the small-scale mining sector through the introduction of new technology, such as the widespread use of excavators, wash plants (trommel), crushing machines (Changfa), water platforms and suction equipment for dredging rivers (Crawford et al., 2016).

The term ASM is used to refer to both artisanal mining and small-scale mining, as this nomenclature is used interchangeably in Ghana. A distinction, however, is made between formally registered as opposed to illicit miners who are referred to as galamseyors (galamsey is a corrupted form of the English expression 'gather and sell'). Formally registered miners have tenure security for the mining concessions they operate (five years with the possibility of renewal for another five years) and the license may be transferable to another citizen with the consent of the Minister responsible for the sector (Mineral and Mining Act, 2006, Act 703). In contrast, galamseyors do not have mining concessions and operate from sites they do not have titles to, hence are operating without regulatory approval from the relevant state institutions, i.e. the Ghana Minerals Commission, Environmental Protection Agency, Water Resources Commission, Forestry Commission or the host Municipal Assembly. Moreover, it is claimed that they do not pay tax and statutory fees, operate in sensitive or prohibited areas (such as forest reserves, water bodies, sacred and culturally significant areas, residential zones etc.) and pay less or no attention to human rights (Owusu-Nimo et al., 2018). Galamseyors have extended their activities to many of the mineralised districts in Ghana and their operations take many forms (Owusu-Nimo et al., 2018). 
The legal form of ASM emerged in 1989 when a Small-Scale Gold Mining Act (PNDC Law 218) was passed to provide for the licensing of such operations in Ghana. The Minerals Commission and the Precious Minerals Marketing Company (PMMC) claim that less than 30 percent of the ASM operators in the country are duly registered and licensed (Aubynn, 2009). It is difficult to estimate the total number of galamseyors, as this varies seasonally and over the years; the number operating in any particular area depends on the richness of the ore and the galamseyors' ability to manoeuvre around the legally acquired concessions. When the quality of ore in an area declines, or the yield becomes poor, the galamseyors move on to other areas. Both indigenes of particular areas and migrants operate in legal and illegal ASM, resulting in it becoming difficult to distinguish between the two groups of operators in an active mining site at any time (Nyame and Grant, 2014). There is a history of foreigners, especially from neighbouring West African countries, settling in mining communities since Independence (Nyame et al., 2009) but the recent 'gold boom' in Ghana has quickened the pace of immigration of foreigners, including the Chinese, into gold mining areas and illegal ASM in particular. Drawing on media reports from China, Crawford et al. (2016) claim that at the height of Chinese involvement in 2012 and 2013, almost 50,000 Chinese nationals migrated to Ghana to engage in small-scale gold mining. The entry of the Chinese was a significant factor in the increased contribution of the sector in gold production from 11 percent in 2005 to 36 percent in 2013 (Crawford et al., 2016). In the gold marketing chain, however, trading channels are entangled making it hard to distinguish between formal and informal sectors in the downstream segment of the ASM chain (Fold et al., 2013).

Large-scale mining, with its long history of operation in Ghana (Dumett, 1998; Ofosu-Mensah, 2011a), contributed substantially to the economy until it began to experience difficulties from the early 1960s through to the mid-1980s. The implementation of economic recovery and structural adjustment policies in the early 1980s helped to reverse the decline of the mining sector (AddoFening, 1997 cited in Ofosu-Mensah, 2011b; Akabzaa, 2009). Today, the large-scale mining sector makes substantial financial contributions to the national economy in the form of corporate income tax, royalties, employee income tax, social security payments and a national reconstruction levy. Companies holding a mining license are required to pay between 3 and 6 percent of their gross revenues in royalties (Larsen et al., 2009). Furthermore, most large-scale 
mining companies engage in corporate social responsibility directed at the surrounding communities affected by their mining activities (Yankson, 2010).

The contribution of the mineral sector to wage employment in Ghana, however, is limited. Aryee (2013) claimed that in 2011, 28,000 people were employed in the large-scale mining sector, including gold mining. The majority of gold miners today work in the ASM sector, which is notoriously difficult to measure; recently it has been estimated that the sector employs one million workers and supports approximately 4.5 million more (McQuilken and Hilson, 2016). Hilson et al. (2018) claim that much of this energy is driven by 'necessity' rather than 'opportunistic' entrepreneurship, though as Langevang et al. (2012) have indicated, it can be hard to distinguish between the two.

\section{Linkages between ASM and large-scale mining in Ghana}

The regulatory environment for mining and access to land are major aspects of the interface between formal and informal mining economies. The beginning of the edging out of indigenous gold producers and their criminalisation stems from the Mercury Ordinance of 1932, which banned the use of mercury for processing gold in artisanal mining. The Colonial Office calculated that this would undermine Ghanaian artisanal production and thereby propel them towards employment in European-owned mines The post-independence era was marked by state ownership of mineral resources acquired through the take-over of various foreign large-scale mining companies (Gough and Yankson, 2012).

The Economic Recovery and Structural Adjustment Programmes (ERP/SAP) adopted in 1983 reversed the nationalist mining policy and SAP conditionality compelled the Ghanaian state to encourage private participation in the mining sector. The establishment of the Minerals Commission and the promulgation of the Minerals and Mining Code in 1986 were significant institutional developments that reflected the new policy paradigm (Akabzaa and Darimani, 2001). The Precious Minerals Marketing Corporation was also established, which became the sole governmental agency for the purchase of the mineral output of small-scale miners, though the government has since opened up the marketing to private licensed buyers. The Small-Scale Mining Law passed in 1989 gave legal status to the sector making the Small-Scale Mining Project (a department of the Minerals Commission) responsible for registering and supervising 
small-scale miners, including assigning them specific areas to operate in. Due to frustrations associated with the registration process, many opt to operate illegally as galamseyors (Akabzaa and Darimani, 2001).

Additional factors have emerged to explain the persistence of illegal ASM. These include the involvement of the local chief in such operations through, for instance, land trading between the miners and local land owners, and the range of employment opportunities provided by the sector (Banchirigah, 2007; Nyame and Blocher, 2010). The proliferation of illegal ASM has also been attributed to the scarcity of land as a result of: the granting of concessions to large-scale mining firms, the high transaction cost involved in obtaining licenses and the non-transferability of mining rights (Andrew, 2003; Hilson and Potter, 2005; Sinding, 2005;), and the endemic poverty of rural areas, unemployment, social or regulatory exclusion (Hilson, 2012; Andrews, 2015). The cost of processing the ASM application fee at the Minerals Commission is GHC 19,169 (US\$ 4,564 at exchange rate US\$ 1= GHC4.2; Personal Communication with Nelson Ahedor, Minerals Commission, Ghana, May 31, 2017). The formalisation process of ASM has not been effective because the government has little or no incentive to do so as the PMMC charged with buying gold does not make any distinction between purchases from legal and illegal ASM. This is at variance with the role of the policy making institutions that are tackling the illegal mining problem (Hilson and Potter, 2005). Discussions on the formalisation of ASM have rather focused on two main issues: first, improved working practices, both for the sake of the miners and the environment; and second, operators' access to mineralised land (Fold et al., 2013). It is the latter that is of interest to this paper.

Turning to land issues, the most pivotal development in the relationship between large-scale mining and ASM was the former's switch from underground to surface mining beginning in the 1980s. All major new mines that came on stream after 1986 are open-pit, requiring a considerable degree of land alienation. The decisions regarding access to land by large-scale mining are taken at the national rather than the local level. Access to land by ASM is supposed to be through a formalisation process but the operators encounter difficulties in attempting to access licenses due to insufficient geological knowledge, shortage of capital, relatively high cost and bureaucracy (Banchirigah, 2007; Fisher, 2007; Hilson and Yakovleva, 2007). Moreover, some ASM operators in Ghana, and elsewhere in Africa, do not intend to regularise their businesses 
(Andrews, 2015). Marginalisation of ASM in terms of access to mineralised land is thus a recurring issue its relationship with large-scale mining. Information obtained from the Minerals Commission, however, seems to indicate that they have taken steps to ease the registration bottlenecks such as: establishment of district offices close to prospective ASM miners; fast and quick inspection of proposed ASM concessions by district officers; payment of processing fees at the district offices of the Minerals Commission; decentralisation of the processing of Environmental Protection Agency (EPA) permits to regional and district levels; and joint inspection of ASM concessions by EPA and Minerals Commission officials. Moreover, the EPA permit process is gradually being devolved to district and regional levels (ISSER, 2017).

Despite these strategies, the formalisation of ASM has not been successful because the policy framework for Ghana's mineral sector has largely prioritised the development of large-scale activities (McQuilken and Hilson, 2016). The weakness of local government has been another factor, since the concentration of power within the centrally appointed District Chief Executives undermines the participation of the other resource users, traditional authorities and assembly members, and can result in political and economic rent seeking behaviour by the District Assemblies (Hirons, 2014). There is also a sizeable gap between what the government believes ASM is and what it actually is. As Hilson and Hilson (2015:2) argue "This misdiagnosis has spawned a regulatory apparatus that has proved to be a formidable barrier for ASM operators who are attempting to transition to the formal economy". Moreover, institutional changes have impeded rather than facilitated formalisation of ASM, including changes in the role of various agencies and the radical change in the administrative set up when the Small Scale Mining Project (SSMP) was launched in the early 1990s (Hilson et al., 2017).

Conflicts have increasingly arisen between the large-scale mining companies, which have legally acquired their mining concessions, and the numerous small-scale or artisanal miners operating illegally in the large-scale mining concessions (Hilson, 2002a, 2002b; Nyame and Blocher, 2010; Nyame and Grant, 2014; Geenen, 2014; Andrews, 2015). Recently, Patel et al. (2016) examined the spatial relationship between large-scale mining and ASM in southern Ghana, where the Central, Western, Eastern and Ashanti Regions intersect, by mapping the spatial overlaps between the two. They show that there is substantial resource competition between the two 
mining types, particularly in the prospecting concessions of large-scale mining. These circumstances can at times lead to violent confrontations (Eshun, 2005) with galamsey operators objecting to the acquisition of large tracts of mining lands by the large-scale mining companies. The prevailing legal and traditional interpretation of the mineral land ownership rights, coupled with the lack of political will to enforce the laws on illegal encroachment of property, have combined to feed into a tense relationship between ASM and large-scale mining operators in which the former have limited scope to pursue their mining activities (Aubynn, 2009). The earlier legal framework - the Mining and Mineral Law of 1986 (PNDC 153) - did not help, though this was corrected in the later version of the framework (Mineral and Mining Law, ACT 709 of 2006) (Banchirigah, 2007). Despite this, the Minerals Commission has not been very successful in persuading large-scale mining companies to release their unproductive mining sites within their concessions to ASM, and land allocated to ASM is often of dubious mining quality. As the District Officer of the Minerals Commission for Wassa West Small-Scale Mining District intimated:

In Prestea another area has been relinquished for ASM purposes. This new area may be divided into around 200 ASM concessions but to be honest no one really knows if there is gold in that area. There is no geological data for that area yet. And in general, as far as I know, there has not been carried out a proper prospecting of the areas designated for ASM by the Minerals Commission. The areas have mainly been selected because they were available.

The challenge of the lack of mineralised land for ASM was echoed at the Head Office of the Minerals Commission in Accra. Prospective ASM operators have no alternative but to operate illegally on the concessions of large-scale mining, which are known to contain gold, leading to conflicts. Despite rising concern among government regulatory agencies, little has been done to address the causes of these conflicts. This is a major source of concern for large-scale mining companies as the operations of illegal ASM interfere with their operations, while galamsey operators resent their livelihood activities being constrained by foreign companies' legal rights to land. According to the Minerals Commission, however, the lack of formalisation of illegal smallscale mining is the main bottleneck to their accessing mineralised land, as the government has demarcated large areas (about 350 square $\mathrm{km}$ ) in several parts of the country for ASM, which are 
being geologically investigated for alluvial and hard rock gold deposits. This land would be licensed to ASM if proved viable. An additional factor that has greatly affected ASM is local operators, both registered and galamseyors, working with foreign partners irrespective of the law stating that the sector is reserved for Ghanaian citizens and the ban on sub-leasing concessions (Crawford et al., 2016). The development of extensive collaboration between Ghanaian and Chinese miners, as well as with traditional authority and government officials, has facilitated access of the latter to mineralised land and hence into galamsey. This has also been a source of violent conflict, however, with clashes between local villagers and Ghanaian and Chinese ASM over access to land resources.

We now turn to a consideration of the implications of these dynamics between ASM and largescale mining for the livelihoods of the populations in our three case study mining towns, starting with Obuasi before turning to Prestea and then Kenyasi.

\subsection{Obuasi}

Obuasi is the principal gold mining settlement in Ghana, located in the southern part of the Ashanti Region. Although artisanal gold mining has been carried out in Obuasi for centuries, it rose to prominence when the British opened a series of gold mines at the end of the $19^{\text {th }}$ century, the most important being the Ashanti Goldfields Company (AGC) (Dickson, 1969). The population of Obuasi increased from around 20,000 in 1960, to 30,000 in 1970, then almost quadrupled in size over the next 30 years, with an additional 50 percent expansion in the following decade rising to approach 170,000 people in 2010. Today, Obuasi is one of the world's richest mining operations. Even though AGC, now Anglogold Ashanti (AGA), has a concession over the entire area, artisanal gold mining still takes place (Ofosu-Mensah, 2011a). The interface between ASM and large-scale mining is central to understanding employment opportunities and livelihood choices in Obuasi.

Before the 1990s when surface mining was adopted, securing employment with AGC was not difficult. In the words of the Municipal Chief Executive (MCE):

Those times if you were schooling in Obuasi immediately you finished standard 7 and you wanted to work you were employed that week. Nobody lacked employment in Obuasi. The mine could employ 18,000 . At the least it was employing about 14,500 . So 
if you multiply those employed by their dependents you will be talking about 75,000 people and the population then was not up to 100,000 so there was no unemployment in Obuasi.

From the 1950s into the early 1980s, ASM was operating minimally on the periphery of Obuasi. This situation changed with the retrenchment of mine workers that reconfigured the town's employment landscape, impacting not just on the miners who had lost their jobs but also on the market traders, masons, carpenters etc. who relied on the presence of large-scale mining for their livelihoods. Thus the rise of ASM, specifically the illegal element since the 1980s, has to be situated within the broader historical context of changing occupational opportunities in Obuasi. Former large-scale mining employees entered ASM after losing their jobs, showing how the histories of the two mining sectors are inextricably interlinked. When people could no longer obtain work with AGC they reverted to informal mining. As the Chairman of the Small-scale Miners' Association explained:

This made some of the people rethink that in the past before the advent of AGC our forefathers were mining the gold using the local materials so why don't we revert to that for us to have our daily bread. So we reverted to digging the ground to look for the little we would get to go and sell. We didn't encroach on where the mines were working but went to places that they had abandoned and planted trees.

According to the Chairman, in July 2011 there were over 10,000 small-scale miners in Obuasi, most of whom were illegal ASM operators. Their rise to prominence in the local economy makes their marginalisation problematic as they fill a void in employment and income generation, which large-scale mining has unable to.

The key challenge facing the illegal ASM operators is how to access a suitable mineralized area, which is especially problematic since the whole of Obuasi and its surrounding areas are part of the mining concession of AGC (now AGA). A focus group discussion with small-scale miners in Obuasi gives an indication of how they try to surmount this challenge:

Before the surface mining emerged, we were working at places where they had their waste and we were using our might to dig the ground but it wasn't big. So it was when the surface mining emerged that the small-scale mining also picked up but the company 
was also protecting its resources so we have passed through a lot of hardships here in Obuasi.

In protecting its concession against intrusion by the numerous illegal ASM operators, AGC had to fight back using the state security as echoed in the words of the MCE:

Unfortunately in trying to fight them, there were a lot of confrontations, inflicting cutlass wounds and so on. Now the mines introduced guard dogs and the people also became very wild and the security would also not spare anyone they get.

As the numbers of illegal ASM operators increased, the conflict between them and AGC escalated as the former turned their attention to encroaching on the underground mining operations using the old abandoned mine shafts of AGC to get to the ore underground and even stealing ore following blasting by AGC. The MCE of Obuasi recalled how:

What happened was that at one point, after the confrontation, with the military and the police, we don't know what happened, the galamsey people also found themselves in the underground and running their own shifts and so on and you know the underground it was do or die affair. If you go there they will attack you. It was bad. We had to employ a lot of diplomacy to get them to agree to leave where they were operating because where the galamseyors were operating would have collapsed this mine.

This illustrates how ASM and large-scale mining are very closely interlinked in the context of Obuasi and the types of conflicts that can arise between informal and formal mining operations.

\subsection{Prestea}

Prestea is located at the north-eastern part of the Western Region, in the most intensively mined district (Wassa West District) in Ghana and possibly in the whole of Africa. Several multinational mining companies operate in the area along with numerous small-scale mining activities. Prestea is entirely the creation of various large-scale mining companies that worked the Prestea concession, starting in the 1920s with the British Ariston Gold Mining Company. After independence, the mine became a state gold mining corporation, which was acquired by Prestea Goldfields in the 1980s and later by Prestea Golden Star Resources (GSR). Prestea witnessed very rapid population growth up to the 1960s reaching 13,246 in 1960, then increased 
only slightly to 15,143 in 1970 , rising to almost 17,000 in 1984 . With the revival of the mining industry in the district in the mid-1990s, there was a corresponding increase in the population to 21,844 in 2000 and subsequently approaching 27,000 in 2010, two-thirds of whom were born in Prestea.

The Prestea underground mining operation declined considerably from 1973, leading to its eventual closure in 1992. The revival of the mining sector in the 1990s, however, resulted in new investment being channelled to Wassa West District by a number of multinational mining companies, largely for surface mining rather than underground operations. As in Obuasi, this switch in type of mining operation resulted in the retrenchment of most miners, many of whom moved into the illegal ASM sector. Prestea, however, turned into an illegal ASM haven attracting workers from other areas where underground miners had been retrenched. In 2007, the central government banned illegal ASM from operating in the Prestea area because of conflicts with large-scale mining. As an illegal ASM operator explained: 'It worried us a lot but we couldn't challenge the government, but we were very sad because it was our source of livelihood'. The government, however, lacked the political will to sustain the ban resulting in illegal ASM operating in many locations in and around Prestea. According to the Member of Parliament for Prestea-Huni-Valley, no concessions could be given to ASM operators as the mineralised land has been given on concession to large-scale mining, including Prestea town. He questioned, however, how a traditional town such as Prestea could be located within a mining concession claiming, "If tomorrow the mining company decides to mine at the chief's palace, the chief and indigenous community have nothing to say", highlighting the precariousness of the town's situation.

The recourse to galamsey as an occupational solution, despite all the associated dangers, was a logical response to the underground mine closure, especially for the many young men in Prestea who faced a lack of alternative income-generating activities. As a young woman in one of the focus group discussions noted: 'Because there are no jobs the boys are now illegal ASM operators. Previously one felt shy to be a galamsey worker, but now that is the order of the day'. A young man added: 'To be a galamsey worker is not our wish but because there are no jobs, that is why we are doing it'. Many of the inhabitants expressed a strong desire for underground mining to reopen, seeing it as the solution to the lack of employment in the town and the growing 
number of illegal ASM operators. Thus, in Prestea the lack of employment opportunities in large-scale mining, as a result of the closure of the underground mine, has compelled retrenched and new miners to turn to galamsey for their livelihoods, as was vividly expressed by one participant in the FGD in Prestea: 'Previously, the mines were employing 5,000 workers but now there is no more underground so a lot of workers are now staying home. As a result of that, those who didn't know anything about galamsey are now involved in the galamsey'. Again, this shows how closely linked ASM and large-scale mining are, with miners moving between formal and informal mining operations as opportunities change over time.

\subsection{Kenyasi}

Kenyasi is located in the heart of the Brong-Ahafo Region and is the centre of the multi-national mining company Newmont's Ahafo operations. The town is the capital of Asutifi District, which is primarily rural with subsistence agriculture being the main economic activity. Hence Kenyasi differs from Obuasi and Prestea in that mining is a fairly recent activity but similar to the other towns both large-scale mining and ASM are present. According to the 2010 Ghana Population and Housing Census, the population of the two adjacent urban settlements Kenyasi 1 and Kenyasi 2 is 5,347 .

Gold mining in the area stems from the arrival of Newmont Gold Mining Company in the mid2000s, located on the Ahafo concession. Contrary to expectations, very few local residents have obtained employment with Newmont but many locals have turned to work as galamseyors, both out of necessity and as opportunities for entrepreneurial activities have arisen (Kala, 2016). As a young, male small-scale miner from Kenyasi explained:

I was looking forward to being employed by Newmont but I didn't get hired. But when I looked at galamseyors and the fact that when they return from work they buy food, I decided to do that. And now I realize it is a good thing to do and better than employment at Newmont.

As in the case of many galamsey operators, this young man entered into ASM by default but views his illegal informal activity as more appealing than working in large-scale mining. This attitude relates to the fact that Kenyasi has a different historical trajectory to Obuasi and Prestea; 
galamsey operators in Kenyasi do not experience the same stigma because the area has no 'golden age of large-scale mining' to use as a reference point.

Another perceived advantage of galamsey is the associated increase in commercial activities in the town arising from artisanal miners' daily expenditure. As an elderly man explained:

The changes that I observed since I was growing up are about hardships that people were going through previously. Newmont came here but it wasn't many people they could employ. After the galamsey started there have been a lot of advantages because the enhanced purchasing power of galamsey operators supports commercial activities. I have observed the hardships that people used to go through when I was growing up being replaced with favourable changes. The town is developing with the benefits accruing from the galamsey, which exceeds that of Newmont.

As most employees of Newmont live in Sunyani, about one hour's journey from Kenyasi and are bussed to work in the mine daily, the residents of Kenyasi have not benefitted from the arrival of large-scale mining in terms of direct employment nor do they reap the benefits of the purchasing power of Newmont employees.

The relationship between ASM and large-scale mining with respect to land access also differs in Kenyasi from Obuasi and Prestea. This is because galamsey activities in Kenyasi occur outside the concession owned by Newmont Mining Company, hence there have been no conflicts over land. The importance of galamsey for Kenyasi was brought home to many residents when the settlement's power generation plant broke down and the galamsey operators were no longer able to work. When this happened, taxis were no longer patronised and commercial activities around the pits slowed down considerably as many artisanal miners returned to their hometowns due to lack of earnings. This shows how dependent Kenyasi is on galamsey and how ASM activities inject much more cash into the local economy than any income earned in large-scale mining. The case of Kenyasi thus illustrates the way in which expectations of benefits from formal mining activities are not necessarily met, and that the economic benefits of informal mining activities can be central to the economy of a small town. 


\section{Impact of changes in large-scale mining and ASM on employment}

The changing relationship between large-scale mining and ASM outlined above has implications for employment within the mining settlements. In Table 1, the Ghana Population and Housing Census Reports show that there has been a decline in formal mining employment in Obuasi. In 1960, when there was virtually no galamsey operation in Obuasi, just under half (45.5 percent) of the employed persons (15 years and above) were engaged in mining and quarrying, which dropped to just 13.3 percent in 2010 (with no means of ascertaining which sector they were employed in). The capital-intensive mechanization programme implemented during the 1980s and 1990s resulted in staffing at Ashanti Goldfields Company (AGC) being reduced from approximately 10,000 in 1996 to less than 6,600 in 2003, while the town grew from around 61,000 in 1984 to approaching 116,000 in 2000. By 2010, the total number of employees of AngloGold Ashanti at the Obuasi mine was just 4,225 plus 1,497 contractors $^{1}$, which amounted to 3.4 percent of the total urban population. As indicated above, many of the retrenched workers from the large-scale mining companies found their way into illegal ASM in Obuasi and elsewhere. The reduction in the workforce of large-scale mining is a clear indication of its declining importance, giving rise to the enhanced role of illegal ASM in generating employment. As Table 1 shows, commerce has now become the dominant sector in Obuasi, employing over a quarter (27.2 percent) of the inhabitants; commerce comprises the buying and selling of goods and services at different scales of operation, though most of the enterprises are micro and smallscale informal enterprises.

${ }^{1}$ www.anglogoldashanti.co.za/subwebs/.../reports10/.../ghana.htm(accessed 23-05-2013) 
Table 1: Occupation of employed persons (15 years and above) in the surveyed towns (percentage)

\begin{tabular}{|c|c|c|c|c|c|}
\hline \multirow[b]{2}{*}{ Industrial Sector } & \multicolumn{2}{|c|}{ Obuasi $^{1}$} & \multicolumn{2}{|c|}{ Prestea $^{2}$} & \multirow{2}{*}{$\begin{array}{r}\text { Kenyasi }^{3} \\
2010\end{array}$} \\
\hline & 1960 & 2010 & 1960 & 2010 & \\
\hline Agriculture, fishing, hunting & 10.6 & 10.1 & 55.6 & 44.5 & 54.6 \\
\hline Mining and quarrying & 45.4 & 13.3 & 21.7 & 18.5 & 11.8 \\
\hline Manufacturing & 9.5 & 10.5 & 6.2 & 7.3 & 7.0 \\
\hline Construction & 1.9 & 3.2 & 0.5 & 1.6 & 1.1 \\
\hline $\begin{array}{l}\text { Electricity, gas, water, sanitary } \\
\text { services }\end{array}$ & 0.3 & 0.4 & 0.7 & 0.2 & 0.2 \\
\hline Commerce & 20.5 & 27.2 & 8.8 & 13.8 & 7.3 \\
\hline $\begin{array}{l}\text { Transport, storage, } \\
\text { communications }\end{array}$ & 1.7 & 3.9 & 2.3 & 2.2 & 1.8 \\
\hline Services & 9.2 & 17.4 & 3.3 & 9.6 & 12.4 \\
\hline All others & 0.9 & 7.5 & 0.9 & - & \\
\hline $\begin{array}{l}\text { Persons seeking work for the } \\
\text { first time }\end{array}$ & - & 6.5 & - & 2.3 & 3.8 \\
\hline Total population & 11,533 & 68,345 & 64,978 & 66,626 & 47,602 \\
\hline $\begin{array}{l}\text { urce: Ghana, Census Reports: } \\
\text { Country; } 2010 \text { Populatio }\end{array}$ & $\begin{array}{l}\text { ation } C e \\
\operatorname{sing} C e r\end{array}$ & a $a$ : Vol. 4 & Charact & cal Aut & ons, Total \\
\hline
\end{tabular}

In Prestea, mining and quarrying employed 22 percent of the town's population in 1960, declining in the intervening years as a result of the closure of the town's underground mining operation in 1992. In the 2010 Population and Housing Census, 18.5 percent of employed persons aged 15 years and above were engaged in mining, many of whom presumably were in the illegal ASM sector. Like Obuasi, the enhanced contribution of commerce, largely an informal economy activity, in the employment structure of Prestea between 1960 and 2010 is clear. Table 2 shows the main source of income of households surveyed in 2011 and 10 years previously. No distinction was made between those involved in large-scale mining and ASM but a greater proportion of the sampled households had members operating in ASM. Despite the loss of wage employment from large-scale mining, in 2001 the main source of income for households in Prestea was from mining ( 26.7 percent) followed by skilled work ( 21 percent), whereas in 
Obuasi, which is more dominated by large-scale mining, it was skilled work (19.4 percent) followed by mining (10 percent). By 2011, the proportion of households with mining as their main source of income had increased appreciably for Obuasi (30.6 percent) and Prestea (44.2 percent) and also in Kenyasi (from 6.3 percent in 2001 to 31.3 percent in 2011), reflecting a move into galamsey as large-scale mining employment contracted. The increase in mining as an activity is most prominent in Kenyasi due to mining being a relatively recent activity (Gough et al., 2018). The 2010 census shows that the district is still predominantly rural with agriculture employing over half (almost 55 percent) of the economically active labour force, whilst almost 12 percent was engaged in mining, most likely in ASM (Table 1).

Table 2: Main sources of income for households in the mining towns, 2001 and 2011 (percentages)

\begin{tabular}{|c|c|c|c|c|c|c|c|c|}
\hline \multirow{2}{*}{$\begin{array}{l}\text { Main household income } \\
\text { source }\end{array}$} & \multicolumn{4}{|c|}{2001} & \multicolumn{4}{|c|}{2011} \\
\hline & Obuasi & Prestea & Kenyasi & Mean & Obuasi & Prestea & Kenyasi & Mean \\
\hline None* & 31.3 & 20.0 & 27.5 & 26.7 & 2.5 & 1.7 & 3.8 & 2.5 \\
\hline Farming & 6.3 & 7.5 & 28.7 & 11.7 & 5.6 & 7.5 & 28.7 & 11.4 \\
\hline Mining & 10.0 & 26.7 & 6.3 & 14.7 & 30.6 & 44.2 & 31.3 & 35.3 \\
\hline \multicolumn{9}{|l|}{ Small Trade } \\
\hline Trade general & 14.4 & 14.2 & 12.5 & 13.9 & 18.1 & 12.5 & 8.8 & 14.2 \\
\hline Petty food \& drink trade & 0.0 & 0.8 & 0.0 & 0.3 & 0.6 & 1.7 & 0.0 & 0.8 \\
\hline Trade in agriculture products & 0.6 & 0.0 & 2.5 & 0.8 & & & & \\
\hline \multicolumn{9}{|l|}{ Big Business } \\
\hline Trade in mining products & 0.0 & 2.5 & 0.0 & 0.8 & 0.6 & 0.0 & 1.3 & 1.1 \\
\hline Shop & 1.3 & 0.0 & 0.0 & 0.6 & 1.3 & 0.0 & 1.3 & 0.8 \\
\hline Guesthouse / hotel & 1.3 & 0.8 & 0.0 & 0.8 & 0.6 & 0.0 & 0.0 & 0.3 \\
\hline \multicolumn{9}{|l|}{ Blue-collar workers } \\
\hline Casual labourer & 0.0 & 0.8 & 0.0 & 0.3 & 0.0 & 0.8 & 0.0 & 0.3 \\
\hline Unskilled work & 0.0 & 0.0 & 1.3 & 0.3 & 0.6 & 0.0 & 1.3 & 0.6 \\
\hline Skilled work & 19.4 & 20.8 & 15.0 & 18.9 & 20.6 & 24.2 & 20.0 & 21.7 \\
\hline Formal employment & 4.4 & 3.3 & 1.3 & 3.3 & 5.0 & 1.7 & 1.3 & 3.1 \\
\hline Other & 11.3 & 2.5 & 5.0 & 6.9 & 13.8 & 4.2 & 2.5 & 8.1 \\
\hline
\end{tabular}




\section{Conclusion}

This paper has shown how mining employment is clearly informalising in Ghana, as miners retrenched from large-scale mining, together with those entering mining for the first time, are becoming ASM operators. Conflict over access to mineralised land has intensified as even registered miners experience difficulties accessing land, compelling illegal ASM operators to extend their operations into the mining concessions of large-scale mining companies. This has made the illegal status of galamsey operations more apparent, incurring the wrath of the largescale mining companies and central government. As demonstrated in the case of Obuasi and Prestea, the conflict over access to mineralised land is a consequence of the state's preference for large-scale mining in terms of land allocation, combined with the high cost and bureaucratic bottlenecks encountered by ASM in the formalisation process. Where galamsey operations have not extended onto the concession of large-scale mining companies, as in the case of Newmont in Kenyasi, there has not been any direct conflict between the formal and informal operators. In this instance, chiefs, farmers and other landowners have released land to ASM operators without being constrained by the illegal status of ASM, illustrating how reactions to informal activities are inconsistent (Schindler, 2014).

As demonstrated in this paper, ASM has become critical for the economy of mining towns in Ghana, both in terms of generating employment and the expenditure of the operators who are sustaining the sale of goods and services. Yet without formal recognition, many illegal ASM operators will continue to encounter difficulties. Until recently, attempts by the state to formalise ASM in Ghana were largely unsuccessful, hence as Hilson et al. (2017) have stated, there is the need to 'reconceptualise formalisation' of the sector. Since land is key to ASM formalisation (McQuilken and Hilson, 2016), the processes involved in acquiring land need to be streamlined to encourage galamseyors to opt to be registered. Accessing land is highly complex, however, with multiple actors, including the state, traditional land owners, traditional authorities, farmers as well as large-scale mining companies, and, as shown here, the dynamics of land delivery differ from place to place. Consequently, flexibility is needed in devising a new formalisation strategy, which requires a clear understanding of the structure and operation of ASM, as well as an innovative approach. One possibility is to draw on the Global Production Network (GPN) as an organising framework, as used by McQuilken and Hilson (2018) in analysing artisanal diamond mining in Ghana, which could provide valuable insights into the sector's organisation, 
the role played by different individuals who populate it, and the nature of the relationship between these individuals. Such an understanding is an essential starting point for formalising ASM.

The Government of Ghana that took over the reins of power in January 2017, however, has taken a very different track to address the issues facing ASM, suspending all such operations since early 2017, including those that are registered. A Multilateral Mining Integrated Project (MMIP) has been launched, designed to streamline the operations of ASM by grouping illegal miners and allocating them with explored lands (ISSER, 2017: 207). The aim is to provide ASM operators access to mineralised land and facilitate the formalisation process, to the benefit of the economy of mining towns and large-scale mining companies. The implementation of the project has been delayed, however, and the ban on all small-scale mining is still in force at the time of writing. Consequently, the affected miners are complaining of the hardships they are experiencing and many have expressed their frustrations through demonstrations, illustrating the need for these issues to be resolved promptly to sustain the economies of mining towns.

\section{References}

Addo-Fening, R (1997) Akyem Abuakwa 1700-1943: From Ofori Panin to Sir Ofori-Atta. Trondheim: Norwegian University of Science and Technology, 233-60.

Akabzaa, T. and Darimani, A. (2001) A Study of Impacts of Mining Sector Investment in Ghana on Mining Communities, Accra: Structural Adjustment Participatory Review Initiative (SAPRI) on Ghana [online] http://www.naturalresources.org/minerals/africa/docs/pdfs/Impact\%20of\%20Mining\%20Sector \%20Investment\%20in\%20Ghana.pdf (accessed March 26, 2009).

Akabzaa, T. (2009) Mining in Ghana: Implications for national economic development and poverty reduction in Campbell, B. (ed.) Mining in Africa: Regulation and Development, New York: Pluto Press, 25-65.

Andrews, J.S. (2003) Potential application of mediation to land use conflicts in small scale mining, Journal of Cleaner Production, 11, 117-130

Andrews, N. (2015) Digging for survival and/or justice? The drivers of illegal mining activities in Western Ghana. Africa Today 62 (2) 2-24.

Aryee, B.N. A. (2013) Contribution of the minerals and mining sector to national development: Ghana's experiment, afroeuro.org/magazine/? p7139 (accessed 19-9-2016) 
Aubynn, A. (2009) Sustainable solution or a marriage of inconvenience? The co-existence of large-scale mining and artisanal and small-scale mining in the Abosso Goldfields Concession in Western Ghana. Resource Policy, 34(1-2) 64-70

Banchirigah, S.M. (2007) Challenges with eradicating illegal mining in Ghana: A perspective from the grassroots, Resources Policy 33, 29-38

Bryant, R. (1996) The politics of forestry in Burma. In Hirsch P, and C. Warren (eds) Politics and Environment in Southeast Asia: Resources and Resistance. London, Routledge.: 107-21

Bryant, R. and Bailey S. (1997). Third World Political Ecology. London, Routledge

Bryceson, D. and Potts, D. (eds) (2006) African Urban Economies: Viability, Vitality or Vitiation? London, Palgrave Macmillan.

Chant, S. (2008) The informal sector and employment in Desai, V. and R.B. Potter (eds.) The Companion to Development Studies, London: Hodder Education. 216-24.

Chen, M.A. (2012) The informal economy: Definitions, theories and policies. WIEGO Working Paper No.1. Cambridge, MA, USA.

COWI (2016) Country reports on mercury trade and use for artisanal and small-scale gold mining: Appendix to the report "Mercury trade and use for artisanal and small-scale gold mining in sub-Saharan Africa” Final Report to World Bank, 12 December, 2016.

Crawford, G., Agyeyomah, C; Botchewey, G; and Mba, A. (2016) The impact of Chinese involvement in small scale gold mining in Ghana. Policy Brief 33110 (May): International Growth Centre.

Dickson, K.B. (1969): A Historical Geography of Ghana. Cambridge: Cambridge University Press.

Dumett, R.E. (1979) Pre-colonial gold mining and the state in the Akan Region with a critique of the Terray hypothesis. Research in Economic Anthropology, Greenwich, Connecticut: JAI Press, Inc. 37-68.

Dumett, R.E. (1998) Eldorado in West Africa: The Gold-Mining Frontier, African Labour, and Colonialism in the Gold Coast, 1875 -1900 Athens: Ohio University Press and Oxford: James Currey.

Eshun, P.A. (2005) Sustainable small-scale gold mining in Ghana: Setting and strategies for sustainability. in Marker, B.R., Petterson, M.G; McEvoy, F. and Stephenson, M.H (eds.) Sustainable Minerals Operation in the Developing World. London: Geological Society. 61-72

Fisher, E. (2007):Occupying the margins: Labour integration and social exclusion in artisanal mining in Tanzania. Development and Change, 38 (4), 735-760. 
Fold, N, Bosse-Jønsson, J., Yankson, P. (2013) Buying into formalization? State Institutions and Interlocked Markets in African Small-scale Gold Mining. Futures, 62, 128-139

Geenen, S. (2014) Dispossession, displacement and resistance: Artisanal miners in a gold concession in South-Kivu, Democratic Republic of Congo, Resources Policy 40, 90-99

Godfrey, P.C. (2011) Towards a theory of the informal economy. The Academy of Management Annals 5(1), 231-77.

Gough, K.V. and Yankson, P.W.K. (2012) Exploring the connections: mining and urbanization in Ghana, Journal of Contemporary African Studies, 30(4), 651-668

Gough, K.V., Yankson, P.W.K. and Esson, J. (2018) Migration, housing and attachment in urban gold mining settlements, Urban Studies (in press)

Hentschel, T., Hruschka, F, Priester, M. (2002) Global Report on Artisanal \& Small-Scale Mining. Prepared for International Institute for Environment and Development, Mining Minerals and Sustainable Development, No. 7 London.

Hilson, G. (2001) A contextual review of the Ghanaian small-scale industry, Mining Minerals and Sustainable Development (76), 1-29.

Hilson, G. (2002a) Harvesting mineral riches: 1000 years of gold mining in Ghana. Resources Policy 28(1-2), 13-26.

Hilson, G (2002b): An overview of land use conflicts in mining communities. Land Use Policy, $19,63-73$

Hilson, G.M. (2004) Structural adjustment in Ghana: assessing the impacts of mining-sector reform. Africa Today, 51, 53-77.

Hilson, G. and Potter, C. (2005) Structural adjustment and subsistence industry: Artisanal gold mining in Ghana. Development and Change, 36(1), 103-131.

Hilson, G., Yakovleva, N. (2007) Strained relations: a critical analysis of the mining conflict in Prestea, Ghana. Political Geography, 26, 98-119

Hilson, G. M. (2012) Poverty traps in small-scale mining communities: The case of sub-Saharan Africa, Canadian Journal of Development Studies 33,180-97.

Hilson G.;and Hilson, A (2015): Entrepreneurship, poverty and sustainability: Critical reflections on the formalization of small-scale mining in Ghana International Growth Centre, Working Paper

Hilson, G. (2016). Farming, small-scale mining and rural livelihoods in Sub- 
Saharan Africa: A critical overview. Extractive Industries and Society 3 (2), 547-563.

Hilson, G; Hilson, A; Maconachie, R.; McQuilken, J; Goumandakoye, H. (2017) Artisanal and small-scale mining (ASM) in sub-Saharan Africa: Reconceptualizing formalization and 'illegal' activity, Geoforum 83, 80-90

Hilson, G.,Hilson, A.; Maconachie, R. (2018) Opportunity or necessity:Conceptualising entrepreneurship at African small scale mines. Technological Forecasting and Social Change, $131,286-302$

Hirons, M ( 2014) Decentralising natural resource governance in Ghana: Critical reflections on the artisanal and small-scale mining sector Futures 62, 21-31

ILO (1972) Employment, Incomes, and Equality: A Strategy for Increasing Productive Employment in Kenya. Geneva: ILO.

Institute of Statistical, Social and Economic Research (ISSER) (2017): The State of Ghanaian Economy in 2016, College of Humanities, University of Ghana, Legon

Kala, M. (2016): Youth entrepreneurship in a small-scale gold mining settlement in Ghana in Gough, K.V.; and Langevang, T. (eds): Young Entrepreneurs in Sub-Saharan Africa, Chapter 12, Routledge, London, New York pp 181-192

Kea, R.A.(1982): Settlement, trade and politics in the seventeeth-century Gold Coast. John Hopkins University Press, Baltimore and London.

Langevang, T., Namatovu, R. and Dawa, S. (2012) Beyond necessity and opportunity entrepreneurship: motivations and aspirations of young entrepreneurs in Uganda, International Development Planning Review, 34, 439-459

Larsen M. N., Yankson, P. and Fold, N. (2009) Does foreign direct investment (FDI) create linkages in mining? The case of gold mining in Ghana in Sumner, A., D. Sanchez-Ancochea, E. Rugraff (eds) Transnational Corporations and Development Policy: Critical Perspectives. London, Palgrave Macmillan, 247-73.

Lourenco-Lindell, I. (2008), Building alliances between formal and informal workers: Experiences from Africa, in Bieler, A., Lindberg, I and Pillay, D. (eds.) Labour and the challenge of globalization: What prospects for transnational solidarity? London: Pluto Press

Maconachie, R. and Hilson, G. (2018) 'The war whose bullets you don't see': Diamond digging, resilience and Ebola in Sierra Leone, Journal of Rural Studies, 61: 110-122

McQuilken J., and Hilson, G. (2016) Artisanal and small-scale gold mining in Ghana: Evidence to inform 'action dialogue' IIED Country Report, August 2016. 
McQuilken, J., Hilson, G. (2018) Mapping small scale mineral production network: The case of alluvial diamonds in Ghana, Development and Change 49(4), 978-1009.

Meagher, K (1995) Crisis, informalization and the urban informal sector in sub-Saharan Africa, Development and Change 26(2), 259-84.

Meagher, K. (2013): Unlocking the informal economy: A literature review on linkages between formal and informal economies in developing countries; Women in Informal Employment Globalizing and Organizing (WIEGO) Working Paper No. 27, April

Nyame, F.K., Grant, J.A., Yakovleva, N. (2009) Perspectives on migration patterns in Ghana's mining industry, Resource Policy 34, 6-11

Nyame, F.K. and Blocher, J. (2010) Influence of land tenure practices on artisanal mining in Ghana'. Resource Policy, 35, 47-53

Nyame, F.K. and Grant, A.J. (2014) The political economy of transitory mining in Ghana: Understanding the trajectories, triumphs, and tribulations of artisanal and small-scale operators, The Extractive Industries and Society 1, 75-85

Ofosu-Mensah, E.O. (2011a) Gold mining and socio-economic development of Obuasi in Adanse. African Journal of History and Culture. 3(4), 54-64

Ofosu-Mensah, E.O. (2011b) Historical overview of traditional and modern gold mining in Ghana. International Research Journal of Library, Information and Archival Studies 1(1), 6-22

Owusu-Nimo, F.,Mantey,J.; Nyarko, K.B.; Appiah-Effah, E. Aubynn, A. (2018). Spatial distribution patterns of illegal artisanal small scale gold mining (Galamsey) operations in Ghana: A focus on the Western Region. Heliyon 4. doi: 10.1016/j.heliyon.2018.e00534

Patel, K; Rogan, J., Cuba, N., and Bebbington, A. (2016) Evaluating conflicts surrounding mineral extraction in Ghana. Assessing the spatial interaction of large and small-scale mining: The Extractive Industries and Society 3(2), 450-463

Portes, A. and Schauffler, R. (1993) Competing perspectives on the Latin American informal sector. Population and Development Review 19(1), 33-60

Potter, R. and Lloyd-Evans, S. (1998) The city in the developing world. Essex: Addison Wesley Longman Limited.

Potts, D. (2007) The state and the informal in sub-Saharan urban economies: Revisiting debate on dualism. Crisis State Working Paper Series No 2 (Working Paper 18: Cities and Fragile States), London School of Economies.

Schindler, S. (2014) Producing and contesting the formal/informal divide: Regulating street hawking in Delhi, India. Urban Studies 51(12), 2596-2612. 
Sinding, K. (2005) The dynamics of artisanal and small-scale mining reforms. Natural Resources Forum, 29 (3), 243-252.

Tan-Mullins, M. (2007) The state and its agencies in coastal resources management: The political ecology of fisheries management in Pattani, southern Thailand, Singapore Journal of Tropical Geography 28, 348-361.

Tokman, V. (1991) The informal sector in Latin America: From underground to legality, in Standing,G. and Tokman, V. (eds.) Towards social adjustment: Labour market issues in structural adjustment, Geneva: International Labour Organization, 141-57.

Van Bockstael, S. (2014) The persistence of informality: Perspectives on the future of artisanal mining in Liberia, Futures, 62, 10-20

Verbrugge, B. (2015) The economic logic of persistent informality: Artisanal and small-scale mining in southern Phillipines, Development and Change 46(5), 1023-1046

Verbrugge, B. and Besmanos, B. (2016) Formalising artisanal and small-scale mining: Whither the workforce? Resource Policy 47, 134-141

Williams, C.C. and Nadin, S. (2012) Work beyond employment: Representations of informal economic activities'. Work, Employment Society 26(2), 1-10.

Yankson, P.W.K. (2010) 'Gold mining and corporate social responsibility in the Wassa West District, Ghana'. Development in Practice 20(3), 354-66.

\section{Acknowledgements:}

We are grateful to the Department for International Development (DfID) and the Economic and Social Research Council (ESRC RES-167-25-0488) for their financial support of the Urban Growth and Poverty in Mining Africa (UPIMA) research programme. The constructive input initially from James Esson and subsequently from two anonymous reviewers and the Editor Gavin Hilson helped improve the paper considerably. 